\title{
Structural Analysis and Tectonic Interpretation of Brittle Failure Structures at Perat Anticline - NE Iraq
}

\author{
Ibrahim S. Al-Jumaily \\ Department of Geology \\ College of Science \\ University of Mosul \\ Rabeea Kh. Al-Hamdani \\ Department of Geology \\ College of Science \\ University of Mosul
}

\author{
Hadeer Gh. M. Adeeb \\ Dams and Water \\ Resources Research Center \\ University of Mosul
}

Mohsen S. Dawlat

Bekhme Dam Office

Resident Engineer

(Received 19/5/2011, Accepted 12/10/2011)

\begin{abstract}
Perat anticline is located about $100 \mathrm{~km}$. northeast Mosul city. It extends NW-SE for about $35 \mathrm{~km}$ through high folded zone of the foreland fold belt of the Zagros collision zone.

Joints were classified into sets and systems according to their relations with three mutually perpendicular tectonic axes. Tension sets are $\mathbf{a c}$ and $\mathbf{b c}$, the first one formed by extension along fold axis accompanying direct compression perpendicular to fold trend, whereas the second is the product of relaxation that succeeded the primary compression. The shear systems are hko, hol and okl developed successively during direct compression and subsequent relaxation episodes of each tectonic pulse.

Planar calcite veins occupying ac, bc and hko joint sets and systems are also prevalent in the study area. Furthermore, singular and conjugate enechelon lenticular vein arrays are displayed within some carbonate units of study area. They enclose acute angles either with $\mathbf{a}$ or $\mathbf{b}$ tectonic axes indicating that they have been formed under two alternating stress regimes. The maximum horizontal compressive stress axis was perpendicular and parallel to the fold axis in the first and second regimes respectively.

The planar and lenticular vein arrays are associated with two orthogonal pressure solution sets (stylolite seams). The peaks of them refer also to the mentioned directions of the maximum horizontal compressive stress. The juxtaposition of these two brittle structure types reflects their kinematic interrelation and hence non-dilation deformation type.

Paleostress analysis of mesofaults falls into compressive, extensional and strike slip states. $\boldsymbol{\sigma}_{\mathbf{1}}$ axis of compressive and strike slip states lies in normal and parallel orientations with respected fold axis. Whereas $\boldsymbol{\sigma}_{3}$ axis of extensional state
\end{abstract}


lies normally to the same fold axis. This state seems compatible with the final uplift of the fold which supplemented also by development of bedding parallel stylolite seams with vertically pointing peaks.

Key words: Perat, joint, vein array, stylolite, mesofault.

$$
\text { التحليل التركيبي و التفسير التكتوني لتراكيب التكسر الهش في طية }
$$

$$
\begin{aligned}
& \text { هدير غازي محمد أديب } \\
& \text { مركز بحوث السدود } \\
& \text { والموارد المائية } \\
& \text { جامعة الموصل } \\
& \text { محسن صالح دولت } \\
& \text { سد بخمة } \\
& \text { دائرة الدهندس الدقيم }
\end{aligned}
$$

$$
\begin{aligned}
& \text { إبراهيم سعد الجميلي } \\
& \text { قسم علوم الأرض الجملي } \\
& \text { كلبة العلوم } \\
& \text { جامعة الدوصل } \\
& \text { ربيع خلف الحمداني } \\
& \text { قسم علوم الأرض لعن } \\
& \text { كلبة العلوم الارض } \\
& \text { جامعة الموصل }
\end{aligned}
$$

\section{الملخص}

تقع طية بيرات المحدبة شمال شرق العراق وتبعد بحدود . [1 كم شمال شرق مدينة الموصل. وتمنت

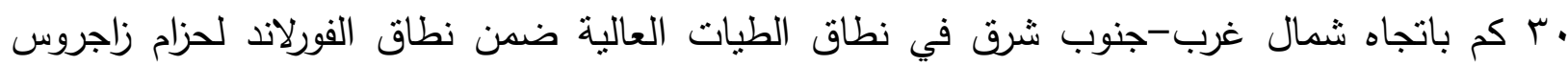
التصادمي.


المحاور التكتونية المتعادة (a, b, c). ظهرت من التحليل مجموعتن شديتين هما(ac, bc)، نكونت

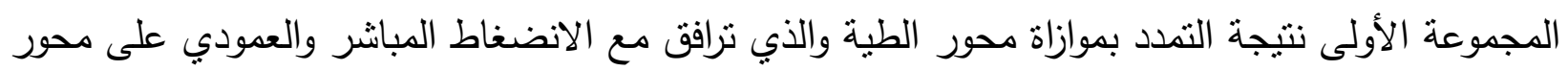

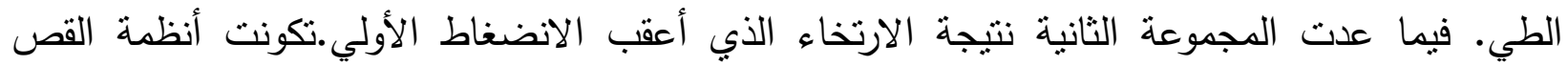
خلال عملية الانضغاط الأولي وفترات الارتخاء التي أعقبت كل نبضة تكتونية.

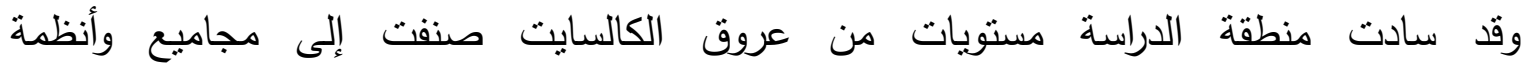

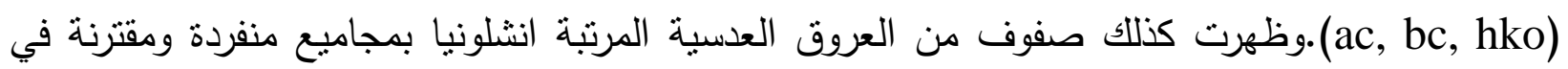

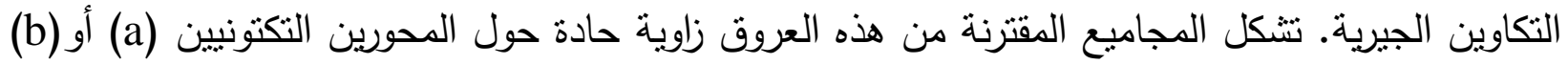
وهذا يشير إلى تكون تلك المجاميع بتأثير نظامين متتاوبين من الإجهاد.وان محور الإجهاد الأفقي الأعظم

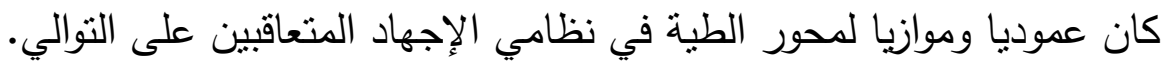


ترافقت صفوف العروق العدسية والمستوية مع مجموعتي صفائح إذابة الضغط المتعامدتين فيما بينهما (Stylolite Seams)، وتنير أيضا قمم مجموعتي هذه الصفائح إلى اتجاهي الإجهاد الانضغاطي الأفقي الأعظم المذكورة أنفا.إن ظهور نوعي التكسر الهش سويةً ذَّعكس العلاقات الحركية لتكونها، فضلا عن نوع التشويه الغير التمددي. وتبين من تحليل الإجهاد القديم للفوالق ظهور حالات الإجهاد الانضغاطية، التمددية والإزاحة المضربية. إن اتجاه محور الإجهاد الأعظم (o, لحالتي الإجهاد الانضغاطية والإزاحة المضربية يكون عموديا وموازيا لمحور الطية، بينما محور الإجهاد الانظغاطي الأصغر (به) لحالة الإجهاد التمددي يكون عموديا لنفس محور الطية. وتتوافق هذه الأخيرة مع عملية الرفع النهائي للطية والتي رافقها تكون صفائح إذابة الضغط ذات القمم الثاقولية على مستويات التطبق.

\section{INTRODUCTION}

The investigated area is situated $100 \mathrm{~km}$. to the northeast of Mosul city northern Iraq. It is a site for uncompleted huge earth dam within Bekhme gorge at NE limb of Perat anticline. Perat anticline is one of the high folded zone structures bordering the Imbricate zone of the Zagros Fold-thrust belt (Jassim and Goff, 2006). This anticline is double plunging and extends NW-SE for about 35 km. (Fig. 1).

Geology of the area is illustrated in (Fig. 2). Generally, the lithologic composition of rock units exposed in the area is built up of alternating beds of limestone, dolomitic limestone, marly limestone, marl and shale. However, clastic deposits dominate at the end of Cretaceous sequence and in most Tertiary units (Omar, 2005; Al-Hamdani, 1991).

Structural style and fold parameters of Perat anticline are illustrated in a synoptic PI- diagram (Fig. 3). It is an open semi-cylindrical and foreland verged fold. The attitudes of fold axis and axial plane are (299/01) and (299/86) respectively.

The aim of investigation is to unraveling the tectonic episodes that affected the fold region throughout analyzing and interpreting different items of brittle failure structures in the area. Worldwide tectonic analysis and interpretation have proved the validity and significance of using various aspects of natural brittle failure discontinuities in this respect (Angelier, 1994; Hancock, 1985; Dune and Hancock, 1994; Van Der pluijm and Marshak, 1997; Bl'es and Feuga, 1986, Shadmon, 2008; Bucher, 1981; Nicolas, 1987; Ramsay and Huber, 1987; Scheidegger, 2001; Taha et al., 1995; Belayneh, 2004; Davis and Reynolds, 1996).

Attitude measurements, field description and characterization of various brittle failure structures were done throughout competent rock exposures along a road cut traverse across the anticline. Later, the gathered data were processed using stereographic technique and computer softwares. The output of this analysis, 
besides the interpretations inferred by field relationships among such structures, were employed to establish the causative tectonic stress regimes for initiation and development of such structures. Finally, the deduced stress regimes were evaluated in the geotectonic context of the northeastern part of Arabian Plate which includes the investigated area.
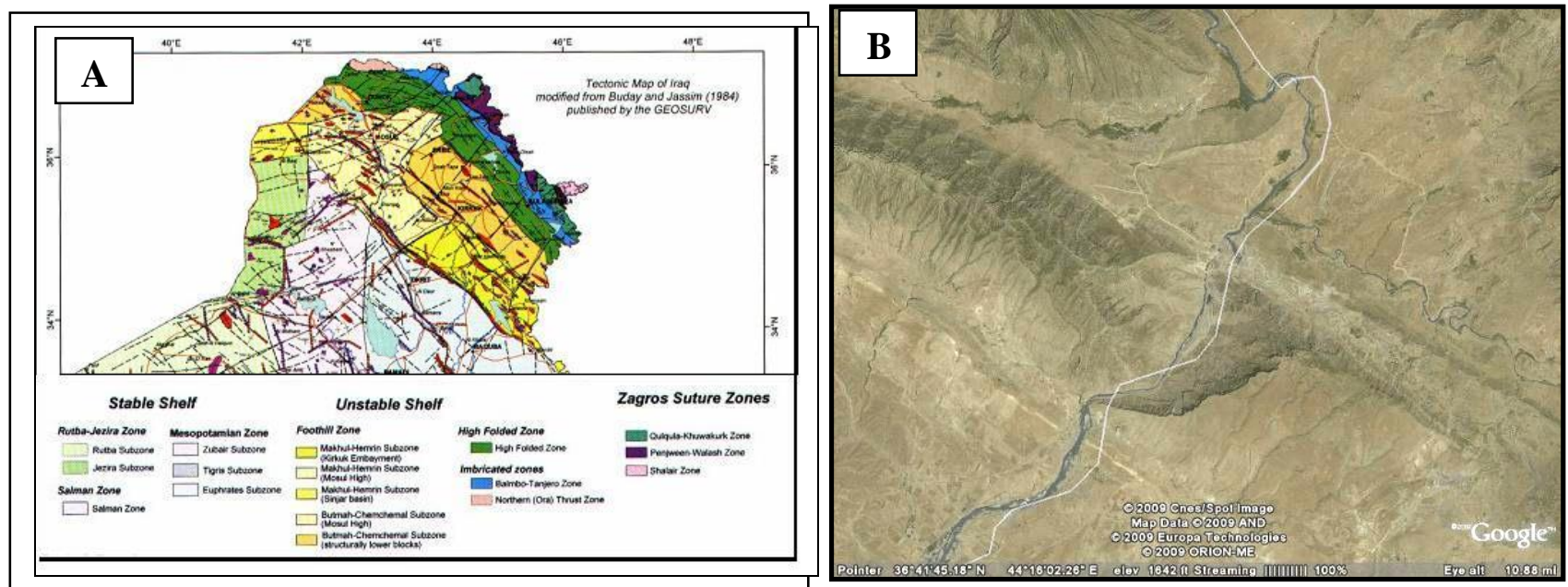

Fig. 1: Location of Study Area in Northern Iraq.

A: Tectonic Map of Northern Iraq (Jassim and Goff, 2006).

B: Google Image of Perat Anticline.

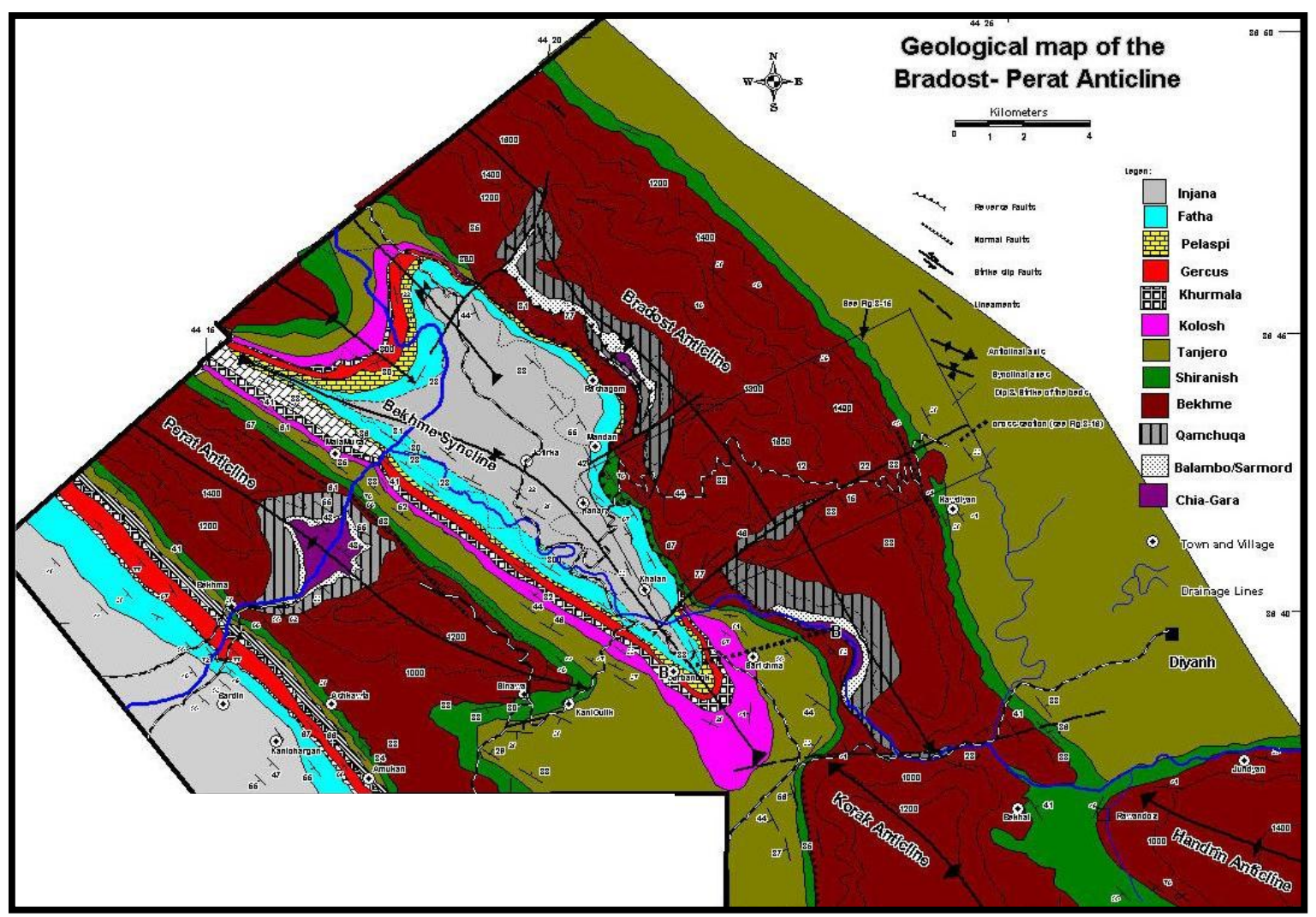

Fig. 2: Geological Map of Perat Aanticline and Surrounding Areas (Omer, 2005). 




Fig. 3: Synoptic PI Diagram Illustrating Structural Elements of Perat Anticline.

\section{DESCRIPTIVE AND GEOMETRIC ANALYSIS}

Four main brittle failure structures were identified in the study area. Following are field descriptions, relations and geometric settings of them:

\section{JOINTS:}

Joints are widespread discontinuities in this area as well as in other parts of the Foreland Fold Belt of northern Iraq. They are classified geometrically into systematic sets and systems following (Hancock, 1985). The base of this classification is the three mutually perpendicular axes (a, b and $\mathbf{c})$. According to this classification, two orthogonal sets namely $\mathbf{a c}$ and $\mathbf{b c}$ are dominantly displayed throughout the area (Plate 1). The other predominant joint system in the area is hko enclosing acute angle bisector either along a (bedding dip) or along b ( bedding strike ) (Plates 2, 3). However, other systems of this classification are relatively less dominant, they are hol and okl systems. (Fig. 4) is a synoptic contoured stereogram for measured joints throughout the investigated traverse. It illustrates well the main joint sets and systems hitherto mentioned. 




Plate 1: Two orthogonal ac and bc tension joint sets in Shiranish Fn. at SW limb of Perat anticline.



Plate 3: Conjugate hko acute about $\mathbf{b}$ shear joint sets in Shiranish Fn. at NE limb of Perat anticline.



Plate 2: Conjugate hko acute about a shear joint sets in Shiranish Fn. at NE limb of Perat anticline.



Fig. 4: A synoptic contoured stereogram for measured joints throughout the investigated traverse. AP: axial plane of Perat anticline. 


\section{VEINS AND TENSION GASHES}

Veins are mineral coating of fracture walls reflecting pore fluid pressure and extension direction during rock fracturing. They are either planar or lenticular in shape. The distribution of the later either be scattered or arranged in individual or conjugate en-echelon sets. The enveloping planes of them are shear surfaces. So the shear sense can be assessed from the angular relations of lenticular veins with enveloping surface (Smith, 1996). The en-echelon arrangement of empty lens like fractures are called as tension gashes. However, some planar veins provide excellent kinematic tools particularly if the pattern of filling are systematic crystals or fibers. And they are classified as syntaxial or antitaxial according to the mineral crystal or fiber growth direction from fracture walls inside or vise versa respectively ( Ramsay and Huber, 1987; Vander Pluijm and Marshaq, 1997; Davis and Reynolds, 1996; Nicolas, 1987; Bl'es and Feuga, 1986). The number of discrete vein layers occupying a vein void reflects the stages of openings of such a fracture and hence the extensional stages can be deduced.

Two orthogonal sets of planar veins were registered throughout study area. One being strike parallel bc, the other is dip parallel ac of bedding (Plate 4). They seem to be syntaxial and some show unique growth stage ( Plate 5), whereas others show multistage of growth (Plate 6). Scattered lenticular veins along bedding strike were observed also at places (Plate 7). Meanwhile, traces of en-echelon arrays of these veins were observed on bedding surfaces with their enveloping lines oblique to bedding strike (Plate 8). 


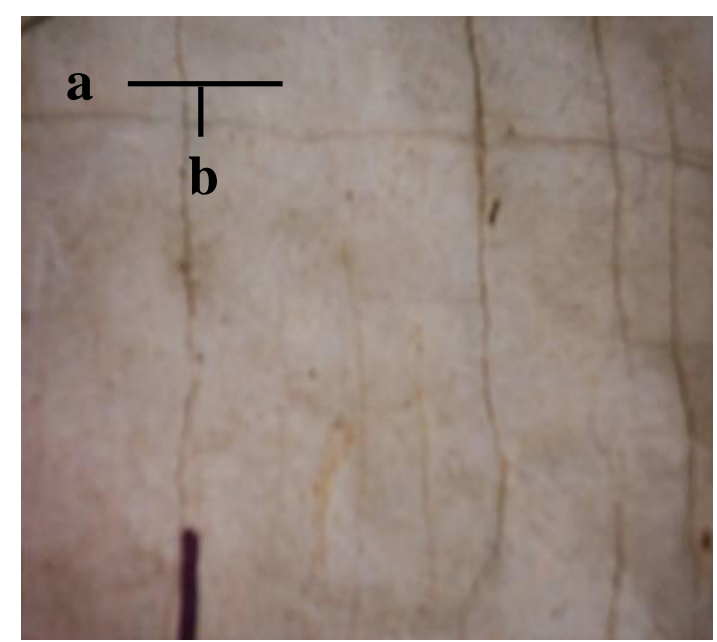

Plate 4: Two orthogonal ac and bc planar vein sets in Shiranish Fn. at NE limb of Perat anticline.
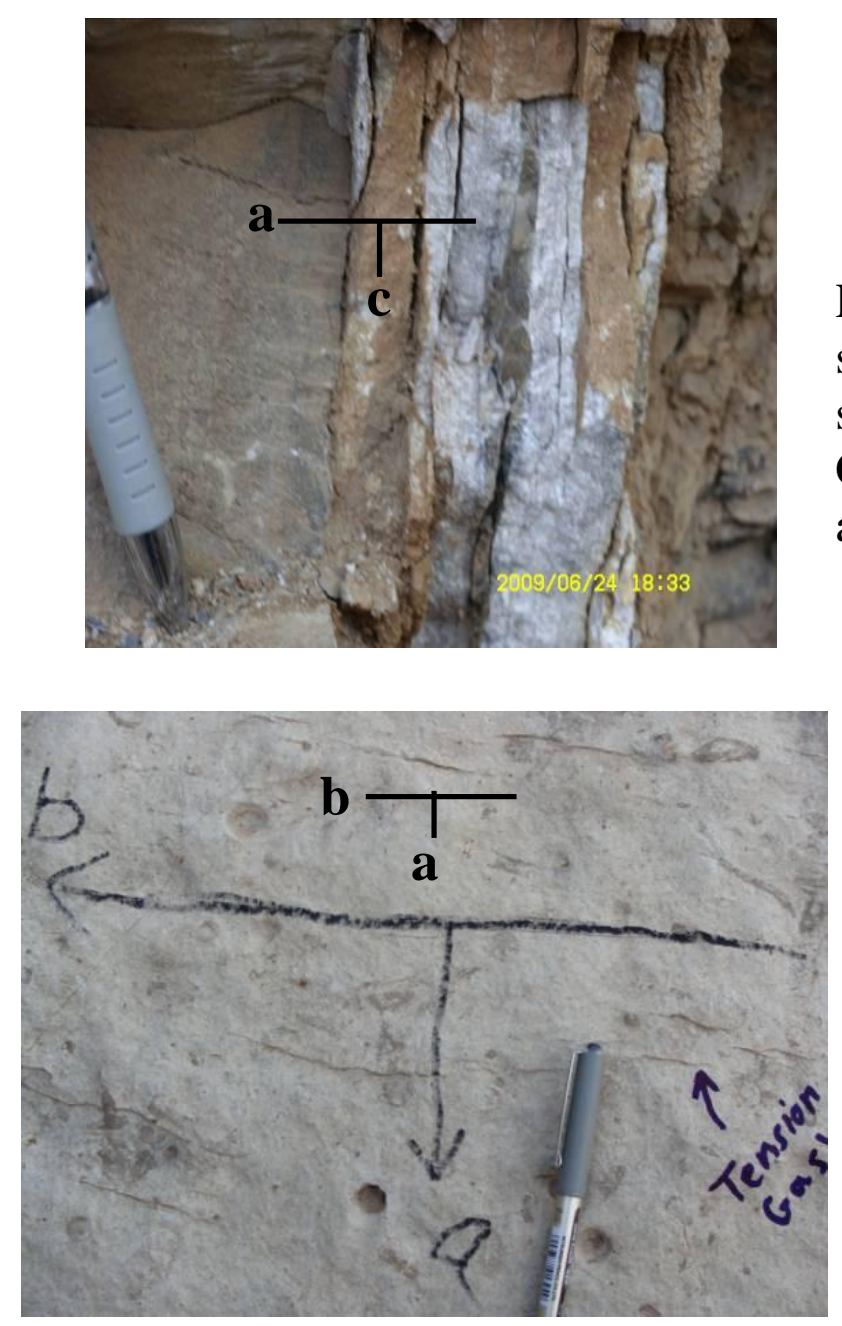

Plate 7: Scattered lenticular veins (tension gashes) along bedding strike of Bekhme Fn. at NE limb of Perat anticline.

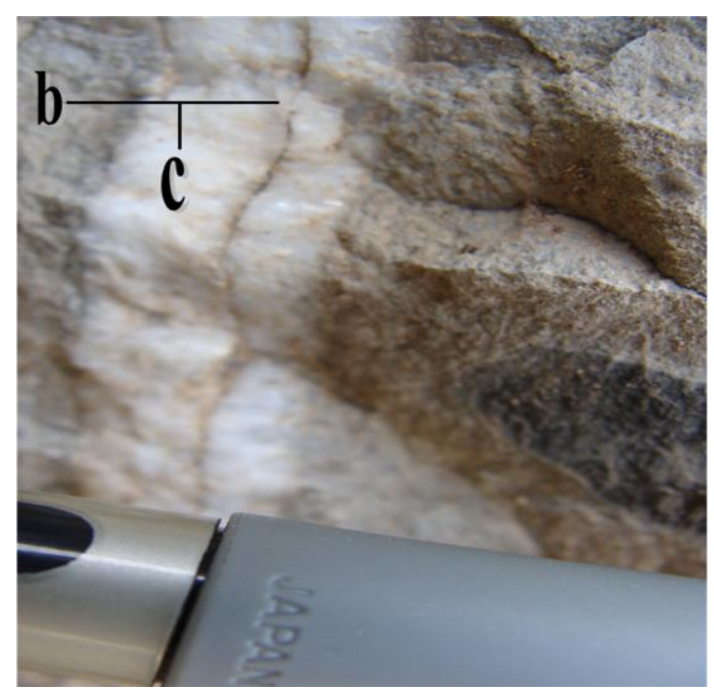

Plate 5: bc section of bedding showing unique growth of a syntaxial ac planar vein in Chiagara Fn. at NE limb of Perat anticline.

Plate 6: ac section of bedding showing multistage growth of a syntaxial bc planar vein in Chiagara Fn. at SW limb of Perat anticline.

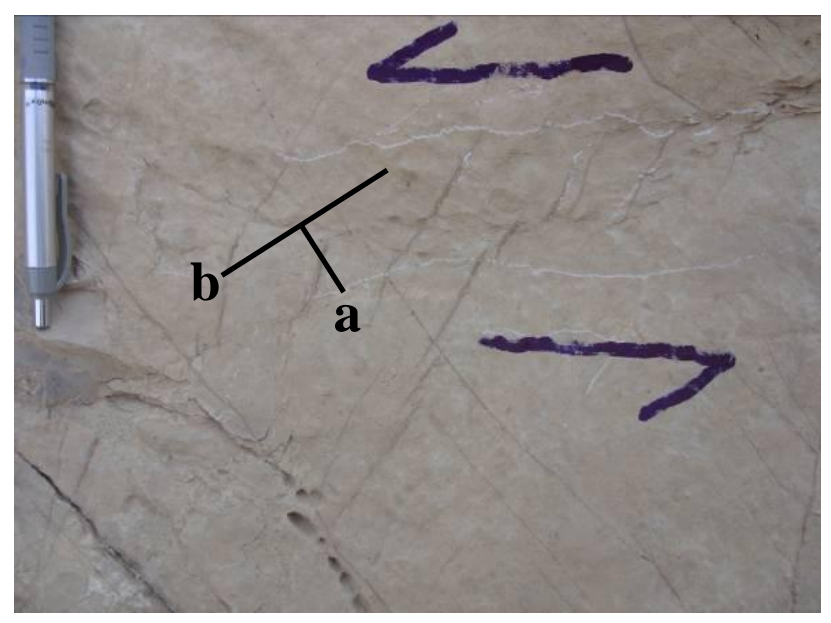

Plate 8: En-echelon array of lenticular veins on bedding surface, the enveloping lines are oblique to bedding strike of shiranish Fn. at SW limb of Perat anticline. 
Groups of tension gashes were documented in ac section of Shiranish Fn. marly limestone beds at the NE limb of the anticline (Plate 9). Continuous intrastrata shearing during flexural slip folding had modified some gash sets into sigmoidal shapes (i.e limb deformation). However, some remained unchanged particularly those at upper level strata indicating their later development with respect to modified sets in lower level strata. Normal array of unmodified and closely spaced tension gashes located also in ac section of strata at hinge zone of the anticline (Plate 10). The development of these tension gashes here is due to pure tension that characterizes the hinge zone (i.e hinge deformation) (Ble`s and Feug`a, 1986).

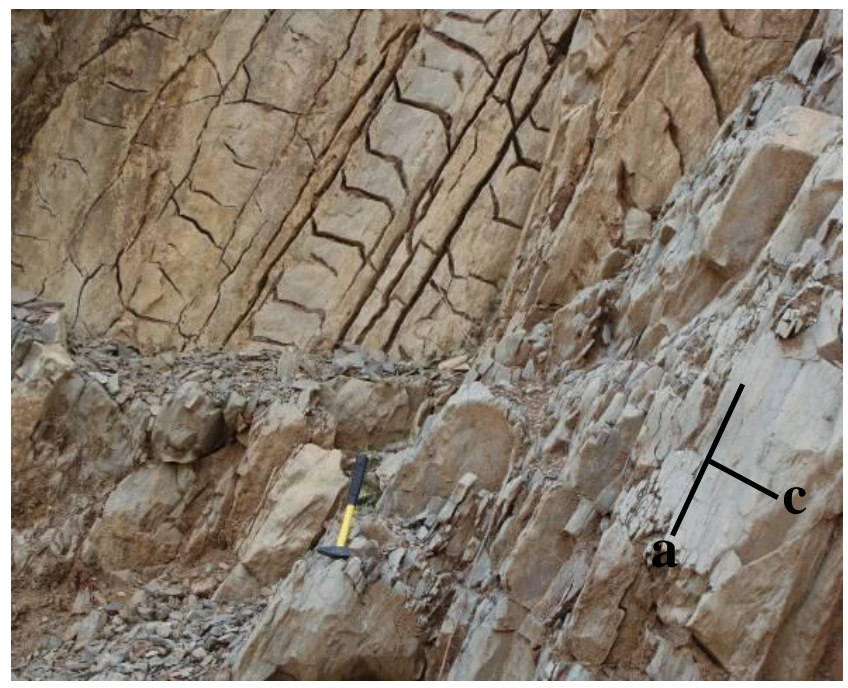

Plate 9: Sigmoidal tension gashes arrays in ac section of Shiranish Fn. marly limestone beds at the NE limb of Perat anticline. (limb deformation).

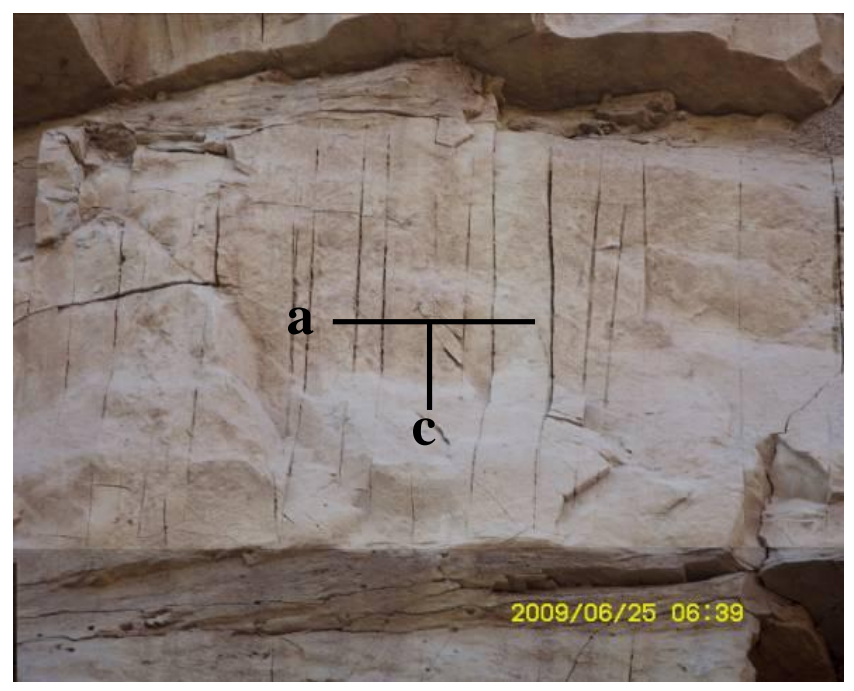

Plate 10: Normal array of unmodified and closely spaced tension gashes in ac section of Qamchuqa Fn. strata at hinge zone of Perat anticline. (hinge deformation).

\section{PRESSURE SOLUTION SURFACES ( STYLOLITE SEAMS)}

They are discontinuities with saw teeth dentitions developed when the rock is intensively compressed from opposite sides with presence of solution. The suture like appearance of these seams is attributed to variant solubility of the rock constituents along the discontinuity plane. Usually, the peaks of stylolite seams oriented normal to their planes. However, obliquely oriented peaks to such planes are termed slickolites. In both cases peak orientation of a stylolite seam refers to compression direction (Shadmon, 2008; Van der Pluijim and Marshak, 1997; Davis and Reynolds, 1996; Nicolas, 1987; Bl'es and Feuga, 1986; Bucher, 1981).Furthermore, Arthaud and Mattauer (1972) in Ble`s and Feuga (1986) had 
considered the bedding parallel stylolitic seams being formed during an extensional stage when the greatest stress axis was vertical.

Stylolite seams are widely distributed throughout calcareous rock units of the investigated area particularly in Bekhme, Qamchuqa and Balambo Formations. The majority of these are of conical type indicating their tectonic origin (Bl'es and Feuga, 1986). However, three sets of these seams were recognized; a bedding strike and dip parallel sets (Plates 11and 12) and a bedding parallel set (Plate 13). Some of them are associated with either planar or lenticular veins indicating kinetic relation between these two types of structures (Plate 14). That is the long axes of the veins are normal to stylolite seams and parallel to their peak orientations (Nicolas, 1987).

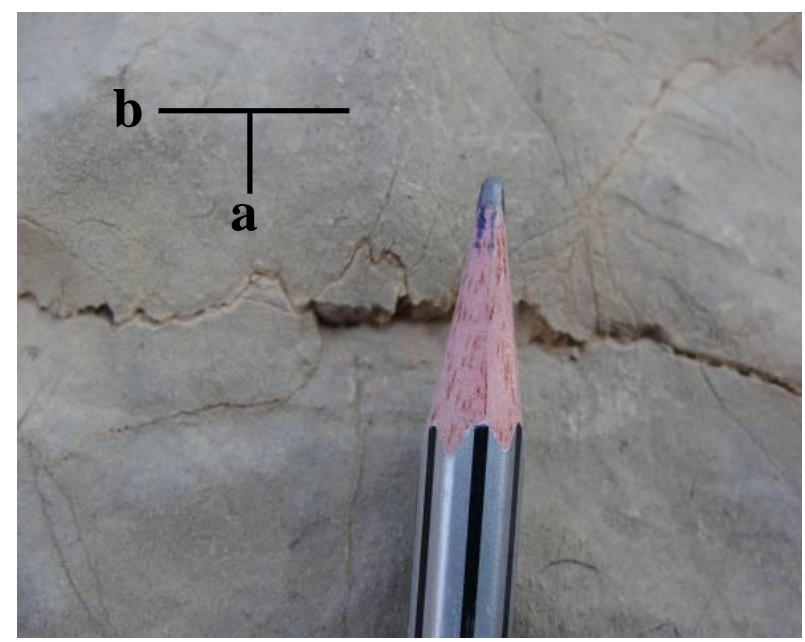

Plate 11: Bedding strike parallel stylolite seam on bedding plane of Balambo Fn. with their peaks pointing toward dip direction of beds.

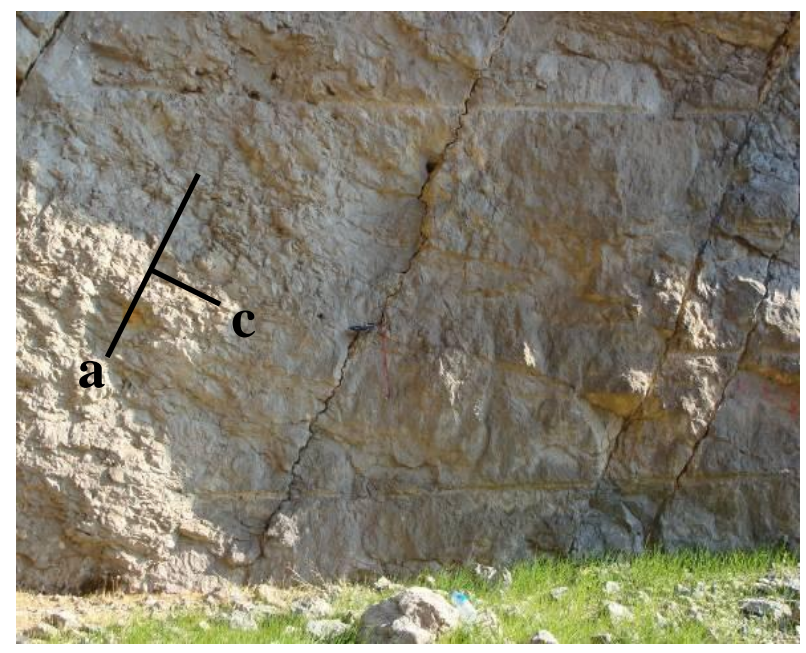

Plate 13: Bedding parallel stylolite seams in ac section with their peaks pointing vertical with respect to bedding planes of Bekhme Fn. NE limb of Perat anticline.

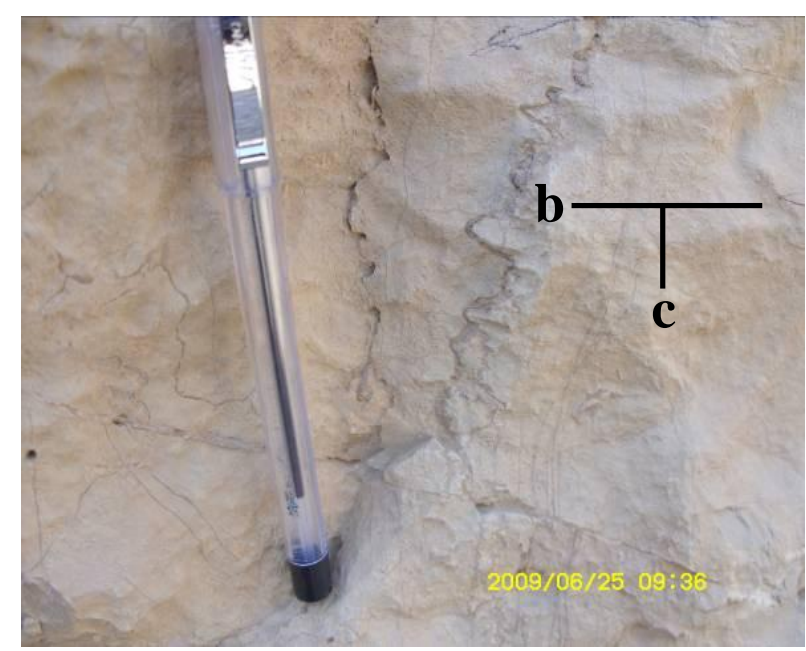

Plate 12: Stylolite seams in bc section of Balambo Fn. with their peaks pointing toward bedding strike.

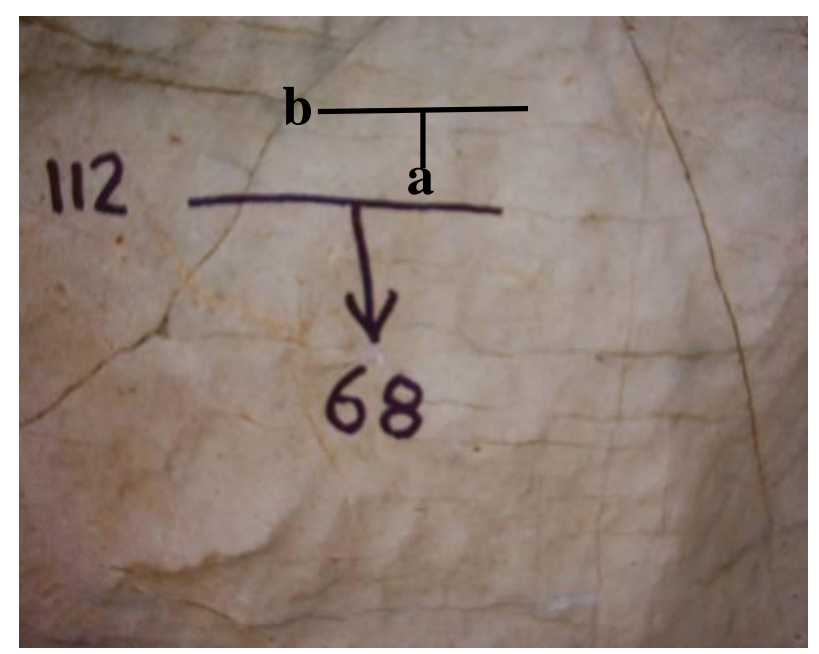

Plate 14: Association of planar veins with stylolite seams in shiranish Fn. NE limb of Perat anticline. 


\section{FAULTS}

Observed and measured faults in the study area are of outcrop scale, and dispose orientations analogous to predominant joint sets and systems. They are reverse, normal and strike slip faults.

Most of reverse faults occupy one set of hol acute about (a) system, and concentrated in the core of the anticline (Plate 15). Most of them terminated by minor folds at their hanging walls (Mitra, 2002). In particular, slip on an antithetic one was so intensive that led to development of an overturned fold in the hanging wall of the fault (Plate 16). However, a conjugate reverse faults occupying okl acute about b system disrupt beds of Khurmala Fn. at the NE limb of the anticline (Plate 17). Most of hol reverse slip faults have well striated surfaces with high rake angles of slip lines (Plate 18).

The observed normal faults occupy hol acute about $\mathbf{c}$ system in the hinge zone of the anticline core. Conjugate sets of these form a graben (Plate 19). A vertical fault also found in the fold core disrupting beds of Chiagara and Balambo formations (Plate 20). However, there is a normal fault with closely spaced arched bc extensional joints and veins concentrated at the footwall closer to the fault trace (Plate 21). Such a configuration might reflects local perturbation of stress field closer to this normal fault. That is the formation of these arched extension joints is update with respect to the associated normal fault (Angelier, 1989).

Strike slip faults expose hko systems, both acute about $\mathbf{a}$ and $\mathbf{b}$. Their slip senses inferred by step facets and smoothing directions of striation scratches on their planes (Plate 22). An interesting cross cutting relation of striations on closely adjacent two planes of these faults is well illustrated in (Plate 23).

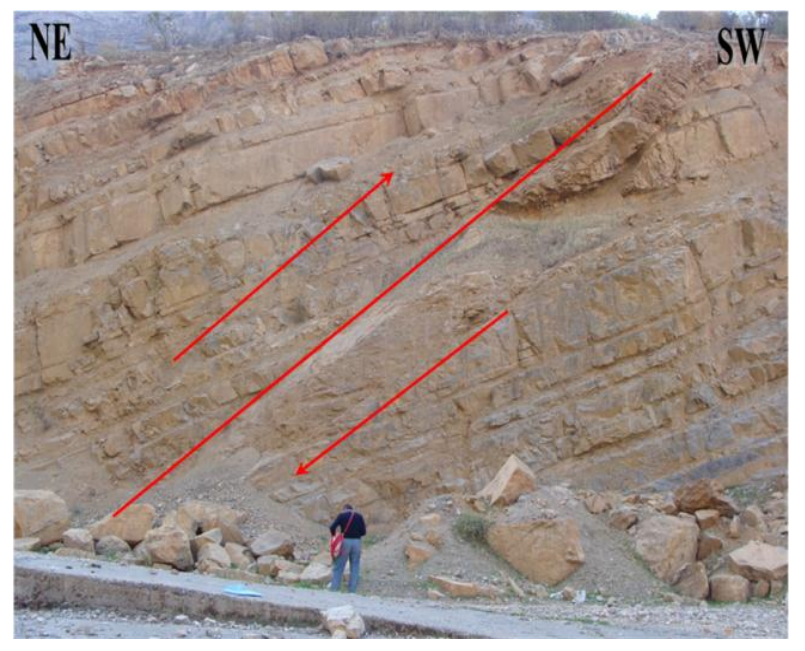

Plate 15: Synthetic hol acute about a reverse slip fault in Chiagara Fn. in the core of Perat anticline.

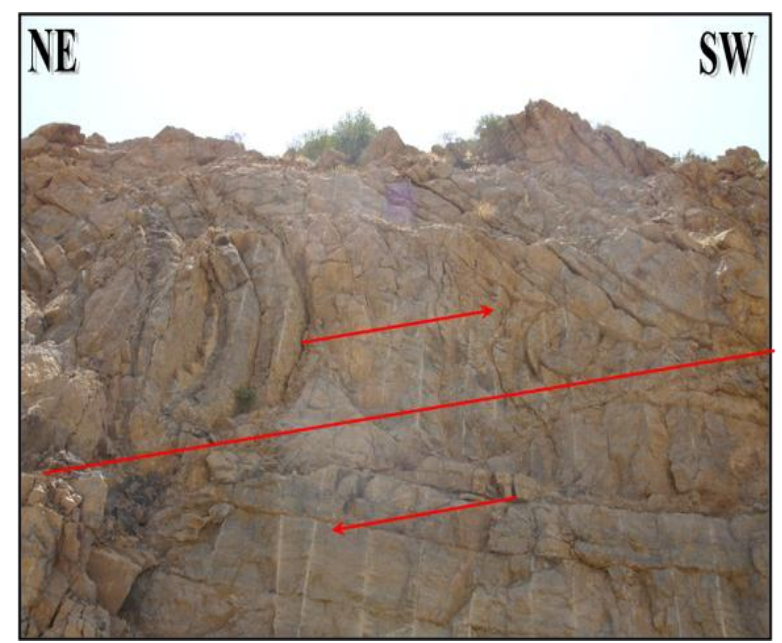

Plate 16: Antithetic hol acute about a reverse slip fault in Chiagara Fn. at SW limb of Perat anticline. 


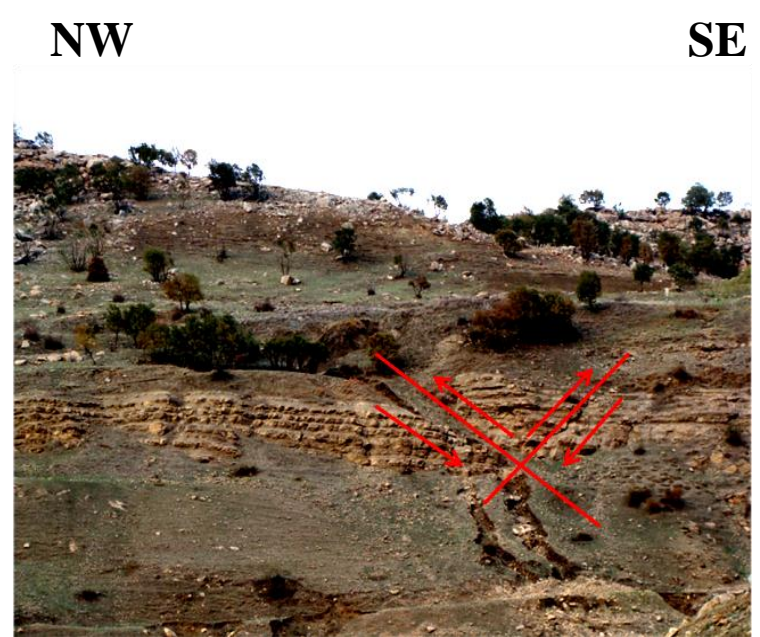

Plate 17:Conjugate reverse slip faults in okl acute about $\mathbf{b}$ system disrupting beds of Khurmala Fn. at the NE limb of Perat anticline.

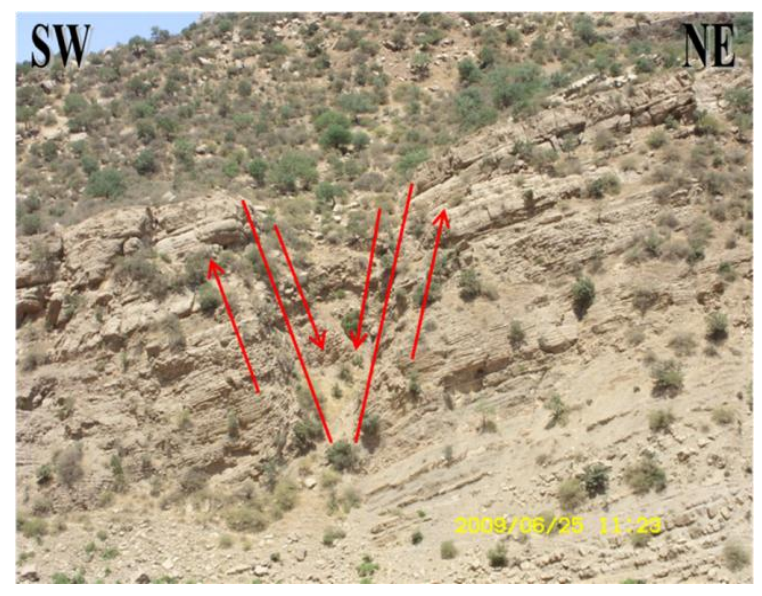

Plate 19: hol acut about $\mathbf{c}$ normal slip faults at Balambo Fn. closer to hinge of Perat anticline

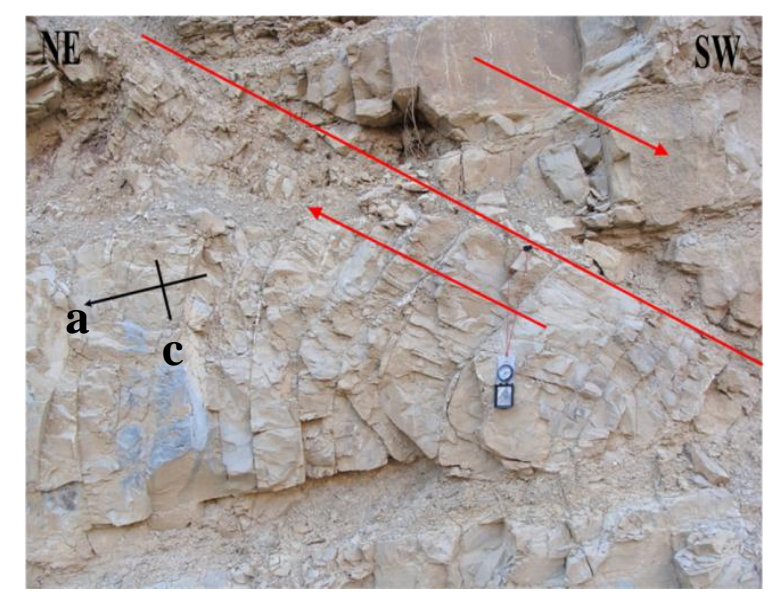

Plate 21: Antithetic normal fault with arched bc tension joints and veins at footwall block. Chiagara Fn. at NE limb close to hinge of Perat anticline.



Plate 18: Striated surface of an hol acute about a reverse slip fault at Chiagara Fn. In the core of Perat anticline

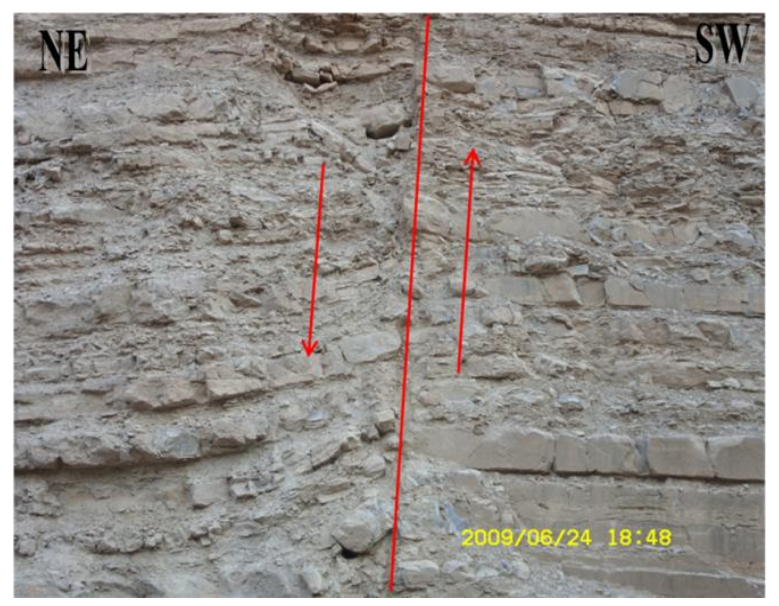

Plate 20: Vertical fault disrupting Chiagara Fn. beds in the core of Perat anticline.

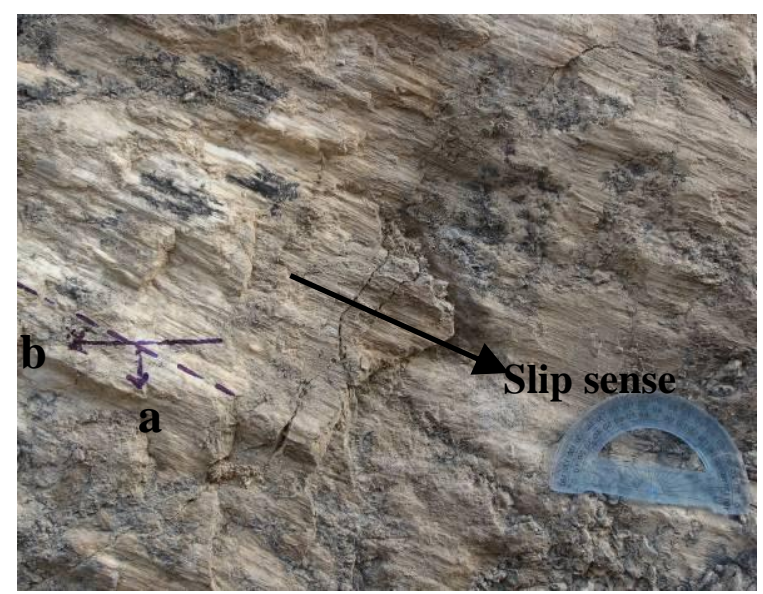

Plate 22:Striated surface of a sinistral strike slip fault in Bekhme Fn. SW limb of Perat anticline. 




Plate 23: Cross cutting relation of striations on closely adjacent strike slip fault surfaces in Balambo Fn. at SE limb of Perat anticline.

\section{KINEMATIC ANALYSIS}

\section{Jonit sest and systems}

According to geometrical configuration, and spatial disposition of joint sets and systems with respect to kinematic indicators ( fold axis, tension veins and gashes, stylolite seams and faults), they were classified tectonically into tension and shear joints (Hancock, 1985; Dunne and Hancock, 1994). The orthogonal ac and bc sets considered as extension joints analogous to the respective orthogonal planar vein sets in the area. Both hko joint systems expressed as shear joints analogous to the strike slip faults. Joints in hol acute about a and okl acute about b systems regarded as compressional shear joints analogous to reverse slip faults in these two systems. Whereas joints in both hol and okl acute about c systems are viewed as extensional shear joints analogous to normal slip faults in these two systems.

Therefore, a primary compression direction (NNE-SSW) normal to anticline trend is postulated from hko and hol acute about a shear joints. However, Interchange between joints of these two systems is accomplished by permutation between $\boldsymbol{\sigma}_{\mathbf{2}}$ and $\boldsymbol{\sigma}_{\mathbf{3}}$ principal stress axes to occupy vertical situation (Hancock, 1985; Angelier, 1989). A secondary extension along fold trend resulted from primary compression was responsible for the formation of ac tension joints. During the relaxation stage following primary compression, new sets and systems of joints formed due to reorientation of stress field. The maximum principal stress axis $\boldsymbol{\sigma}_{\mathbf{1}}$ became parallel to fold axis while the minimum principal stress axis $\boldsymbol{\sigma}_{\mathbf{3}}$ became perpendicular to fold axis within bedding. This new stress field configuration led to development of hko acute about $\mathbf{b}$ shear joints together with bc tension joints. However, okl acute about $\mathbf{b}$ shear joints were developed due to the permutation between $\boldsymbol{\sigma}_{2}$ and $\boldsymbol{\sigma}_{3}$ of this stress field as mentioned above. During the final uplift of the structure following folding stage, extensional stresses were dominated in either of two orthogonal directions. Extensional shear joints of hol 
acute about $\mathbf{c}$ were formed when the principal stress axis $\boldsymbol{\sigma}_{\mathbf{3}}$ was normal to fold axis. Alternatively, extensional shear joints of okl acute about $\mathbf{c}$ were formed when $\sigma_{3}$ became parallel to fold axis.

The sequential development of joint sets and systems according to this scenario is very difficult if not impossible to follow by field relations (i.e. overprinting, cross cutting and termination) (Van der Pluijim and Marshak, 1997; Hancock, 1985; Georg Mandl, 2005). A controversial view obtained when such field relations were applied. Therefore, it is in the opinion of the authors that these joint sets and systems were the output of pulsation manner of stress regime. Each pulse composed of a compressive state followed by a relaxation state. So same groups of joints introduced in the succeeding pulses and interference among individual joints of these groups make it impossible to follow their sequential development.

\section{VEINS AND STYLOLITES}

The compressive and extension stress states extracted from joint architecture of the anticline were supported by kinematic indicators like planar, en-echelon arranged lenticular veins and tension gash arrays, together with associated stylolite seams. A compressive stress state directed NE-SW is assured by peaks of stylolite seams in this orientation (Plate 11 and Fig.5). This is also complemented by planar veins trending in this orientation, and lenticular veins and tension gashes with their long axes in the same direction (Plate 14). However, extension direction deduced by the later structures is in WNW-ESE orientation parallel to fold axis (Fig. 6).This extension direction is considered as secondary byproduct of primary compressive stress regime normal to fold axis. Furthermore, another compressive stress state directed NW-SE expressed by peaks of another set of stylolite seams displayed subnormal to previously mentioned set (i.e. their peaks pointing to strike of bedding) (Plate 12). Another set of vein and tension gash structures oriented in accordance to this direction (Plates 7, 8 and 10). Extension direction deciphered from the later ones lies in NNE-SSW orientation (Fig. 7).

Thus it seems reasonable that the first assemblage of stylolites with their complementary veins and tension gashes are the product of the primary compressive regime directed normal to fold trend. Whereas the second assemblage of such indicative structures are the product of the followed relaxation stage in which the principal stress axes were reoriented as illustrated in joint interpretation.

Moreover, bedding parallel stylolite seams with vertically pointing peaks refer to bedding parallel stretch directed also in NNE-SSW orientation (Plate 13). This stretch is accompanied with the final uplift stage succeeding folding process as stated before. Such bedding parallel stretch state might be responsible also for development of bc planar veins and so oriented tension gashes as well (Plate 10). 


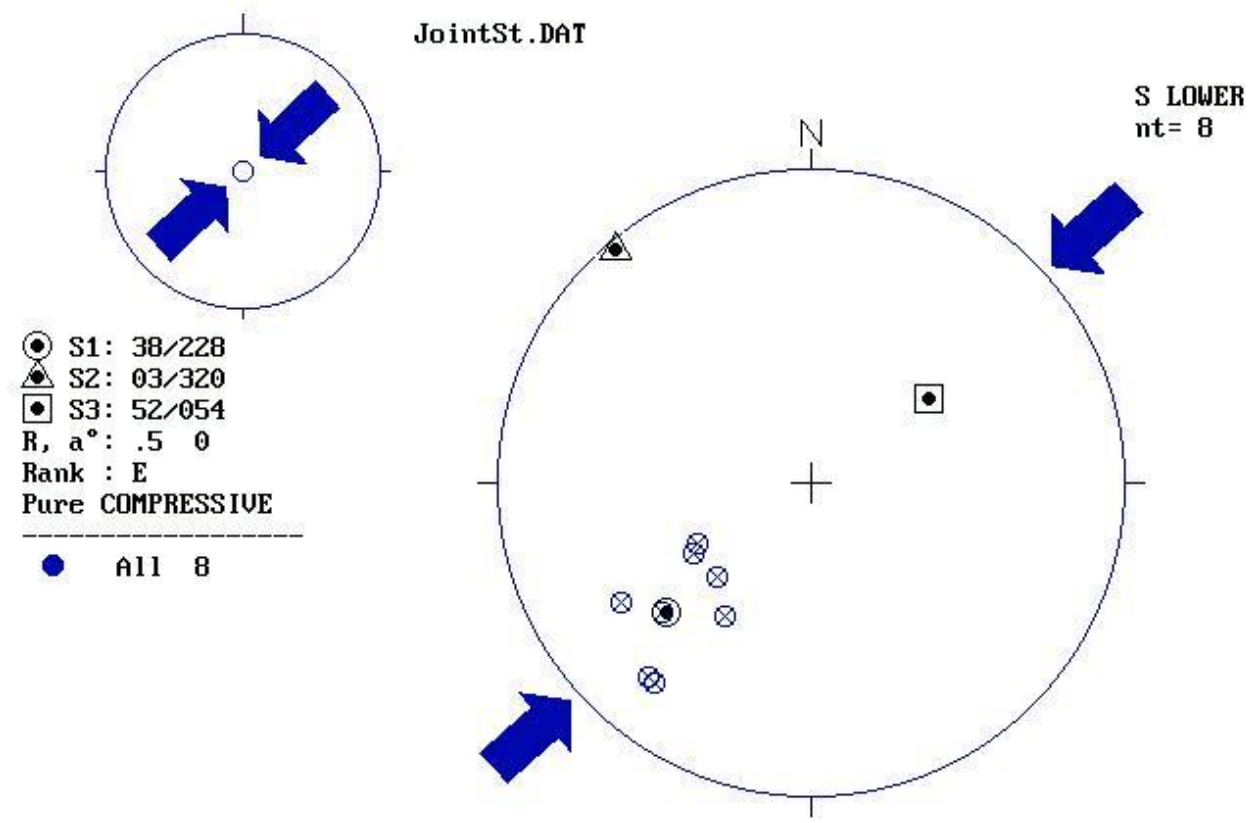

Fig. 5: NE-SW Compressive Stress state Inferred by Bedding Strike Parallel Stylolite Seams with their Peaks Pointing in this Orientation.



Fig. 6: WNW-ESE Extension Stress State Inferred from Planar ac Veins and Tension Joints. 


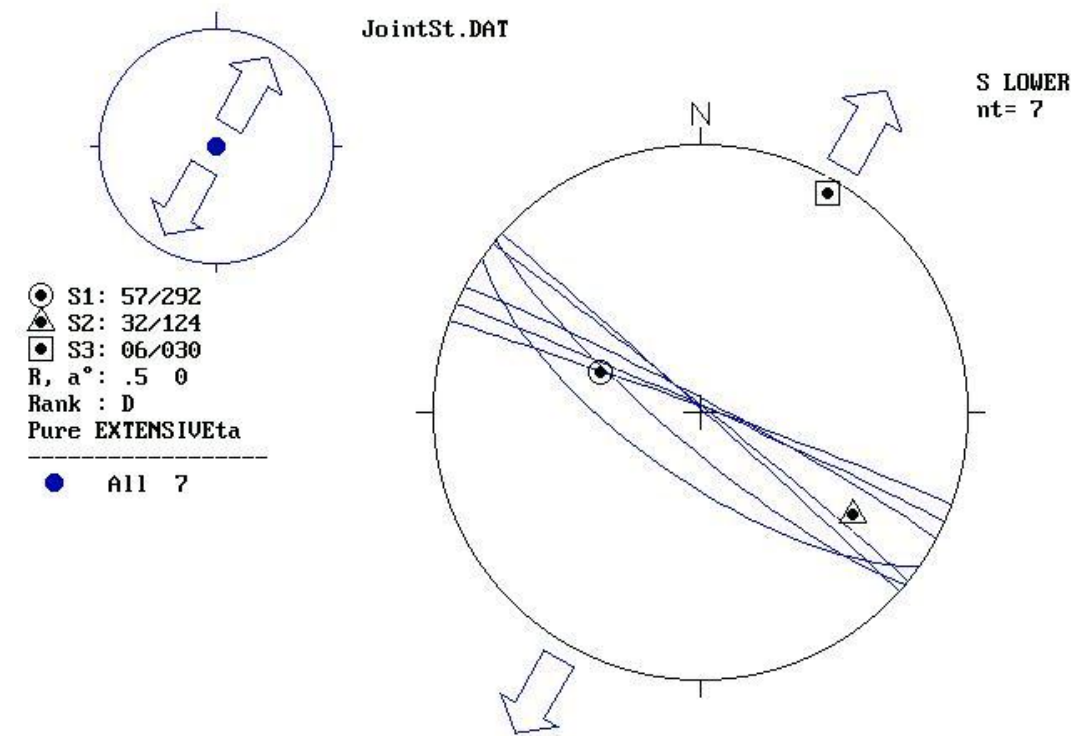

Fig. 7: NNE-SSW Extension Stress State Deduced by bc Veins and Tension Joints.

\section{FAULT SLIPS}

The scientific results of fault slip analysis were obtained using Win-TENSOR, a software developed by Dr. Damien Delvaux of the Royal Museum for Central Africa, Tervuren, Belgium (http://users.skynet.be/damien.delvaux/Tensor). Stress tensors obtained by this analysis are tabulated below (Table 1) and illustrated by stereograms (Figs. 8 - 16).

Furthermore, the whole fault slip data were tested collectively applying $\mathbf{P}$ (compression) and $\mathbf{T}$ (tension) axes technique and using GEORIENT software. The output of this test showed the vary orientations of these axes (Figs. 17and 18). This assures the activity of multi-stress tensors deduced by aforementioned technique (TENSOR software). 
Table 1: Paleostress Tensors Resulted from Faults Slip Analysis at Perat Anticline.

\begin{tabular}{|c|c|c|c|c|c|c|c|}
\hline $\begin{array}{c}\text { Tensor } \\
\text { no. }\end{array}$ & $\begin{array}{c}\text { Fault } \\
\text { no. }\end{array}$ & $\boldsymbol{\sigma}_{\mathbf{1}}$ & $\boldsymbol{\sigma}_{\mathbf{2}}$ & $\boldsymbol{\sigma}_{\mathbf{3}}$ & $\begin{array}{c}\text { Stress ratio } \\
\mathbf{R}\end{array}$ & $\begin{array}{c}\text { Tensor } \\
\text { type }\end{array}$ & Figure \\
\hline 1 & 43 & $05 / 024$ & $03 / 114$ & $83 / 234$ & 0.58 & $\begin{array}{c}\text { Pure } \\
\text { Comp. }\end{array}$ & 8 \\
\hline 2 & 7 & $05 / 251$ & $12 / 160$ & $76 / 003$ & 0.58 & $\begin{array}{c}\text { Pure } \\
\text { Comp. }\end{array}$ & 9 \\
\hline 3 & 5 & $03 / 322$ & $07 / 052$ & $82 / 209$ & 0.43 & $\begin{array}{c}\text { Pure } \\
\text { Comp. }\end{array}$ & 10 \\
\hline 4 & 18 & $04 / 198$ & $84 / 354$ & $02 / 108$ & 0.36 & $\begin{array}{c}\text { Pure } \\
\text { Strike } \\
\text { slip }\end{array}$ & 11 \\
\hline 5 & 9 & $14 / 274$ & $62 / 033$ & $23 / 177$ & 0.33 & $\begin{array}{c}\text { Pure } \\
\text { Strike } \\
\text { slip }\end{array}$ & 12 \\
\hline 6 & 12 & $06 / 334$ & $59 / 234$ & $28 / 067$ & 0.51 & $\begin{array}{c}\text { Pure } \\
\text { Strike } \\
\text { slip }\end{array}$ & 13 \\
\hline 7 & 6 & $80 / 349$ & $09 / 148$ & $03 / 238$ & 0.55 & $\begin{array}{c}\text { Pure } \\
\text { Extension }\end{array}$ & 14 \\
\hline 8 & 3 & $56 / 056$ & $28 / 200$ & $16 / 299$ & 0.48 & $\begin{array}{c}\text { Pure } \\
\text { Extension }\end{array}$ & 15 \\
\hline 9 & 2 & $59 / 244$ & $29 / 075$ & $04 / 342$ & 0.5 & $\begin{array}{c}\text { Pure } \\
\text { Extension }\end{array}$ & 16 \\
\hline
\end{tabular}

The stress tensors obtained by this analysis involve compressive, strike-slip and extension stress states. The directions of the maximum principal stress $\sigma_{1}$ of the compressive and strike-slip tensors, and those of the minimum principal stress $\boldsymbol{\sigma}_{3}$ of the extension tensors seem compatible with the general trends of primary and secondary compressive stress regimes manifested from joints, veins and stylolites. Some discrepancies in this respect might be attributed to reactivation of preexisting fractures, block tilting following development of such faults and to local perturbation of stress field. The primary compressive stress state NNE-SSW represented by tensors ( 1 and 4$)$ established the majority of reverse and strike slip faults in the area. Normal faults represented by tensor (8) are byproduct extensional structures due to secondary tensional stress $\left(\sigma_{3}\right.$ in WNW-ESE direction) related to the primary compressive stress cited above. Tensor (3) attributed to a group of reverse faults developed due to a secondary compressive stress state in NW-SE direction. This state may belong to relaxation episode following the NNE-SSW primary compressive regime. In relaxation episode $\boldsymbol{\sigma}_{\mathbf{1}}$ 
and $\boldsymbol{\sigma}_{\mathbf{3}}$ permute their attitudes so as $\boldsymbol{\sigma}_{\mathbf{1}}$ became parallel to fold trend. In this respect, normal faults represented by Tensor (7) are considered as extensional structures $\left(\sigma_{3}\right.$ in NE-SW direction) of such relaxation episode. Tensors (2 and 5) deduced by other reverse and strike slip faults, might indicate to secondary compressive stress states that ought to anticlockwise rotation of the Arabian plate during its oblique collision against Eurasian plate. (Authemayou et al., 2006; Agard et al., 2005; Molinaro et al., 2005; Alavi, 2004; Mohajjel and Fergusson, 2003; Talebian and Jackson, 2002; Numan, 2001a and b; 1997). The tensor (9) expressed by a little number of normal slip faults might be regarded as extensional $\left(\boldsymbol{\sigma}_{3}\right.$ in NNW-SSE direction) byproduct of such secondary compressive state related to plate rotation. Strike slip faults of tensor (6) might represent the relaxation episode of the hitherto cited secondary compressive state where $\sigma_{1}$ and $\sigma_{3}$ permute their locations so as $\sigma_{1}$ took NNW-SSE direction.

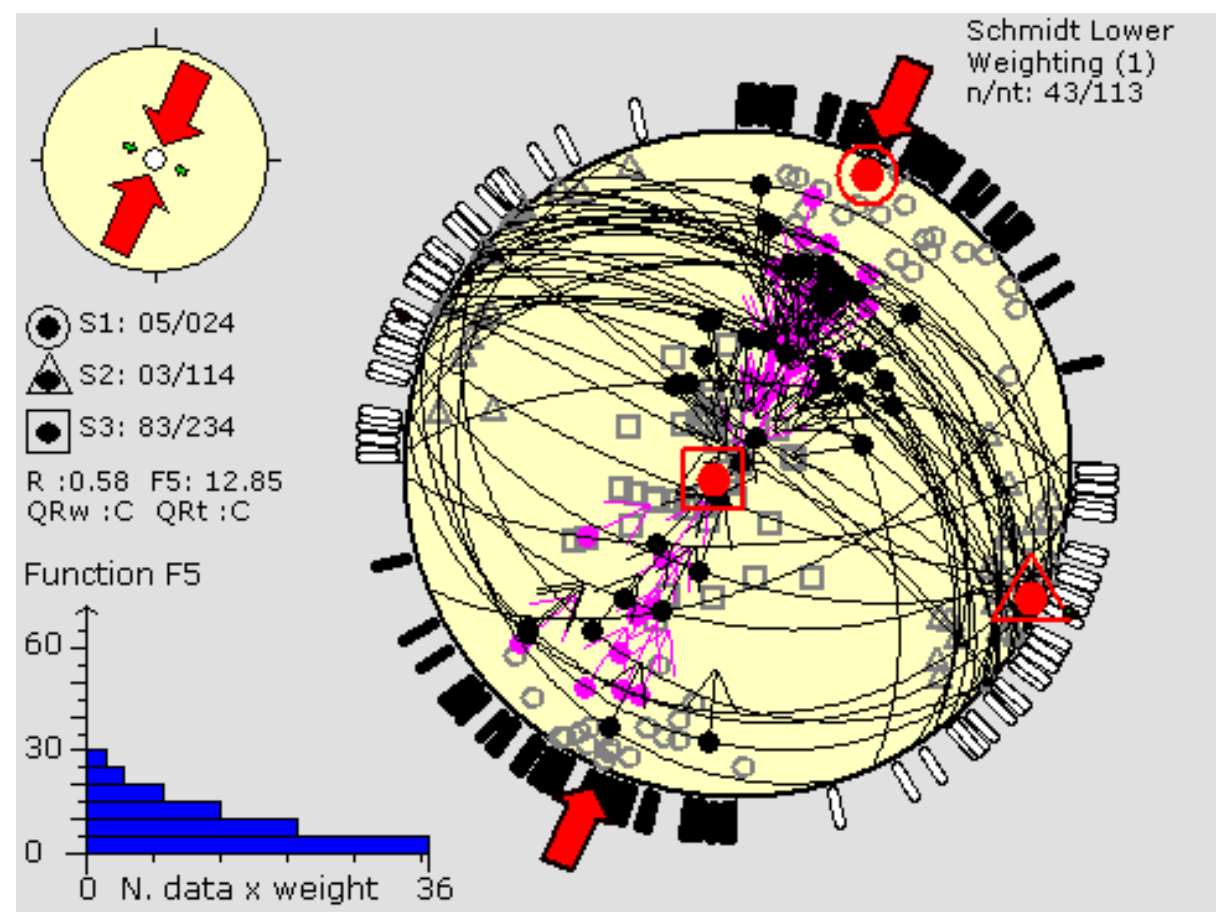

Fig. 8: NNE-SSW Pure Compressive Stress State Deduced by Analysis of Reverse Faults in Perat Anticline. 


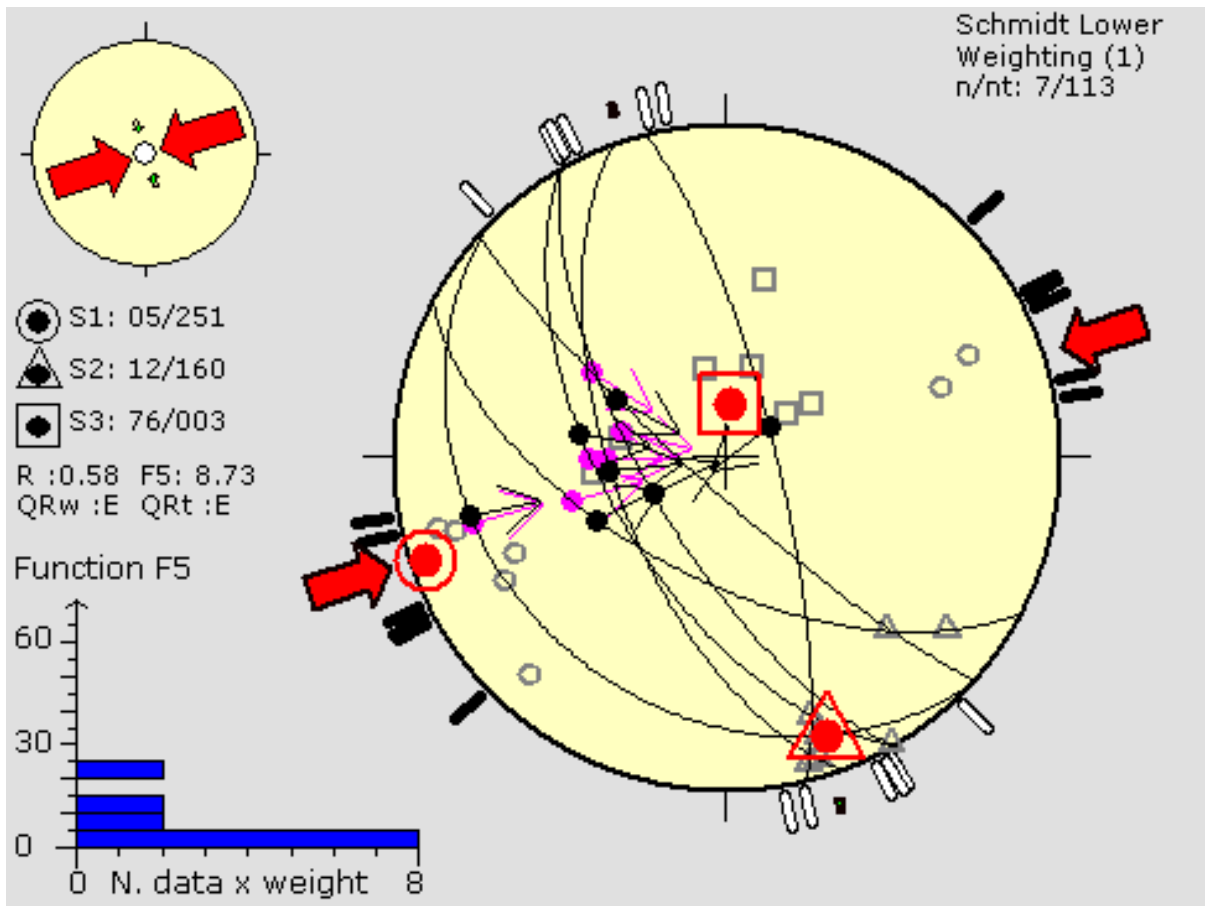

Fig. 9: ENE-WSW Pure Compressive Stress State Deduced by Analysis of Reverse Faults in Perat Anticline.

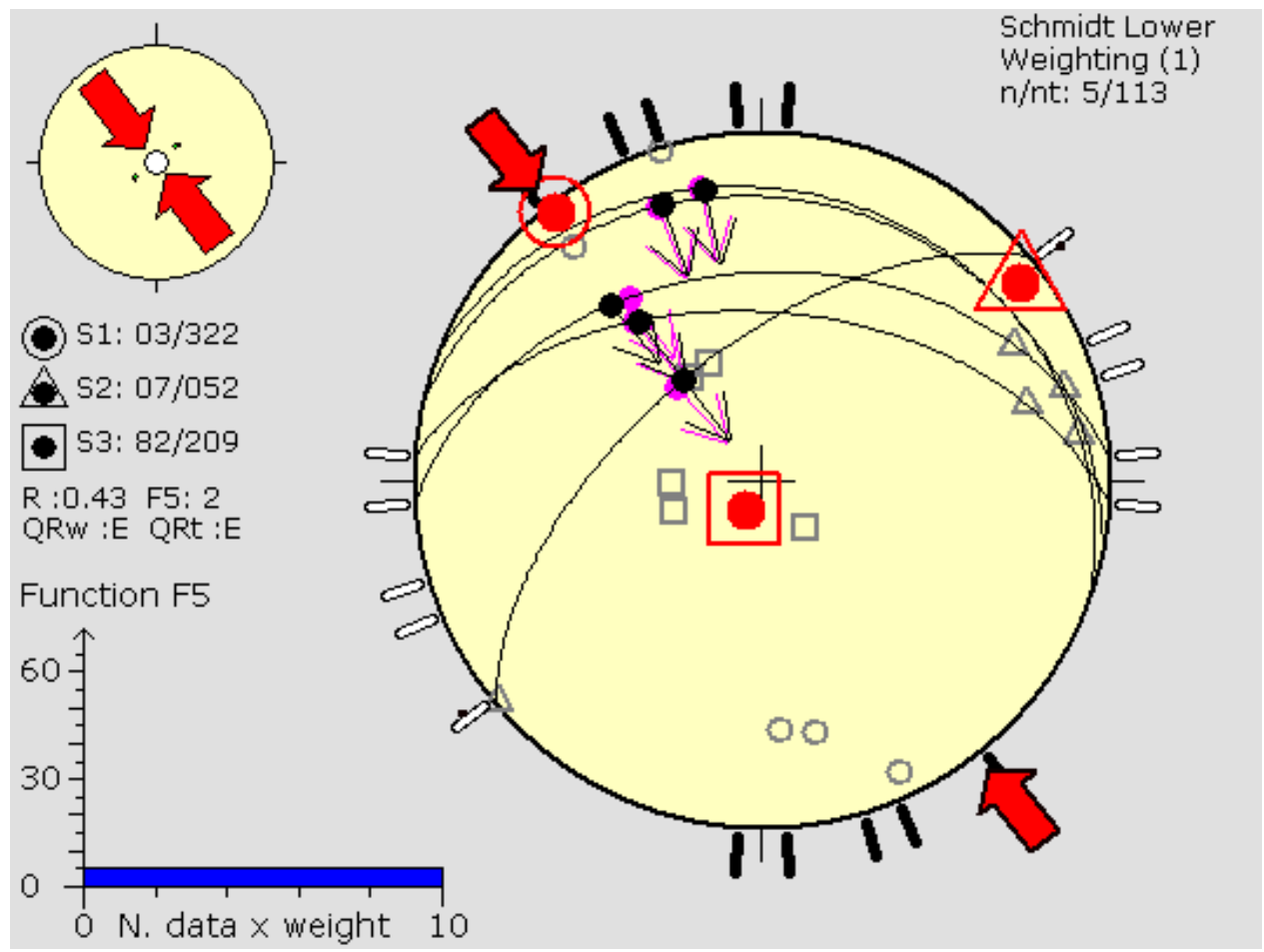

Fig. 10: NW-SE Pure Compressive Stress State Deduced by Analysis of Reverse Faults in Perat Anticline. 

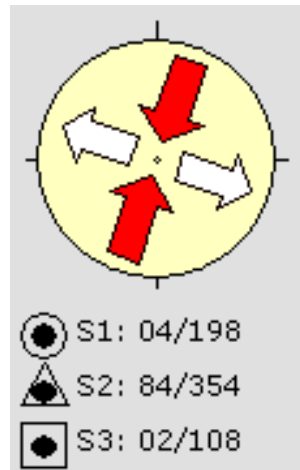

$R: 0.36 \quad F 5: 10.88$ QRW :D QRt :D

Function F5


Fig. 11: NNE_SSW Pure Strike Slip Stress State Deduced by Analysis of Strike Slip Faults in Perat Anticline.


R :0.33 F5: 14.76 QRW : E QRt:E

Function F5
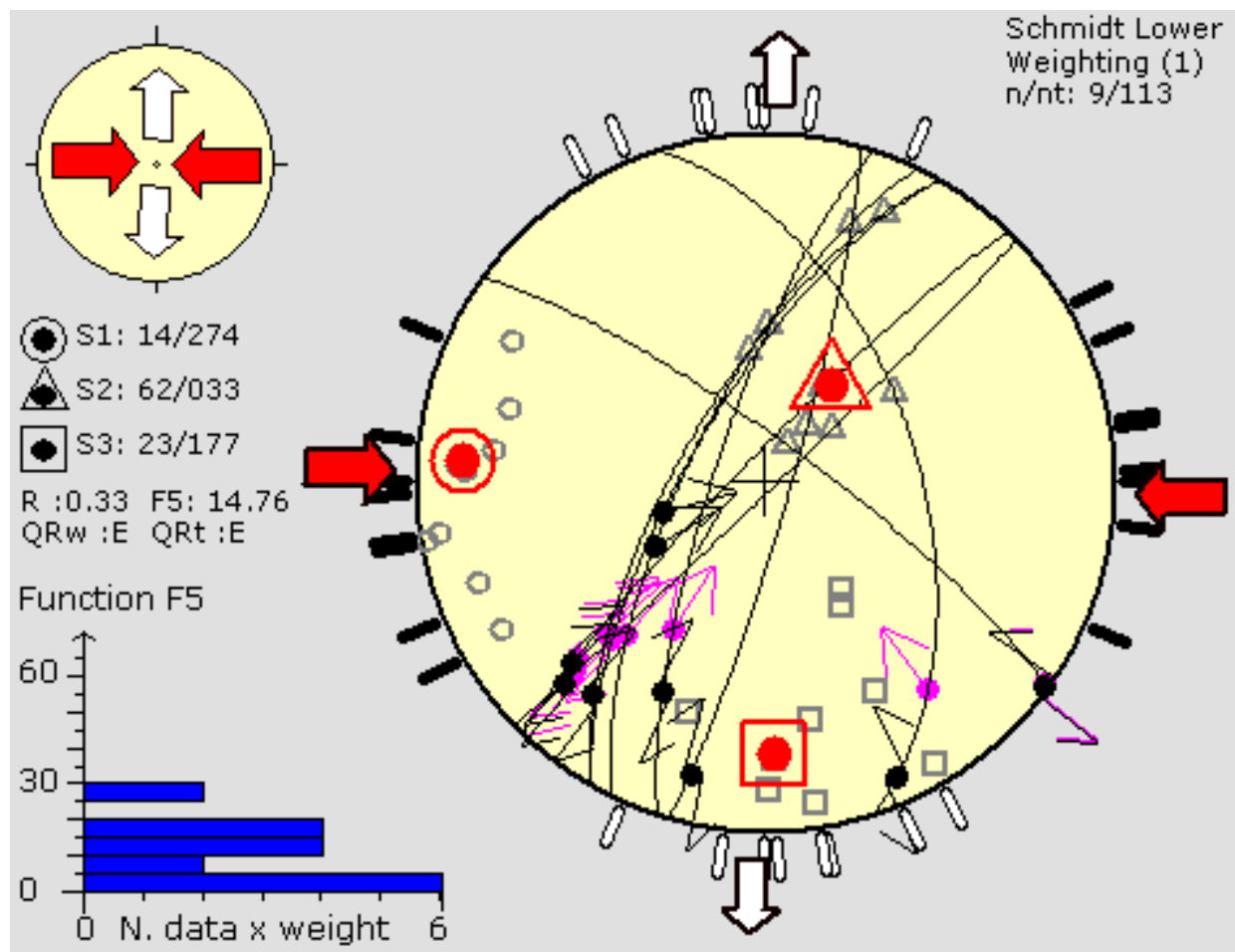

Fig. 12: E-W Pure Strike Slip Stress State Deduced by Analysis of Strike Slip Faults in Perat Aanticline. 




Fig. 13: NNW-SSE Pure Strike Slip Stress State Deduced by Analysis of Strike Slip Faults in Perat Anticline.

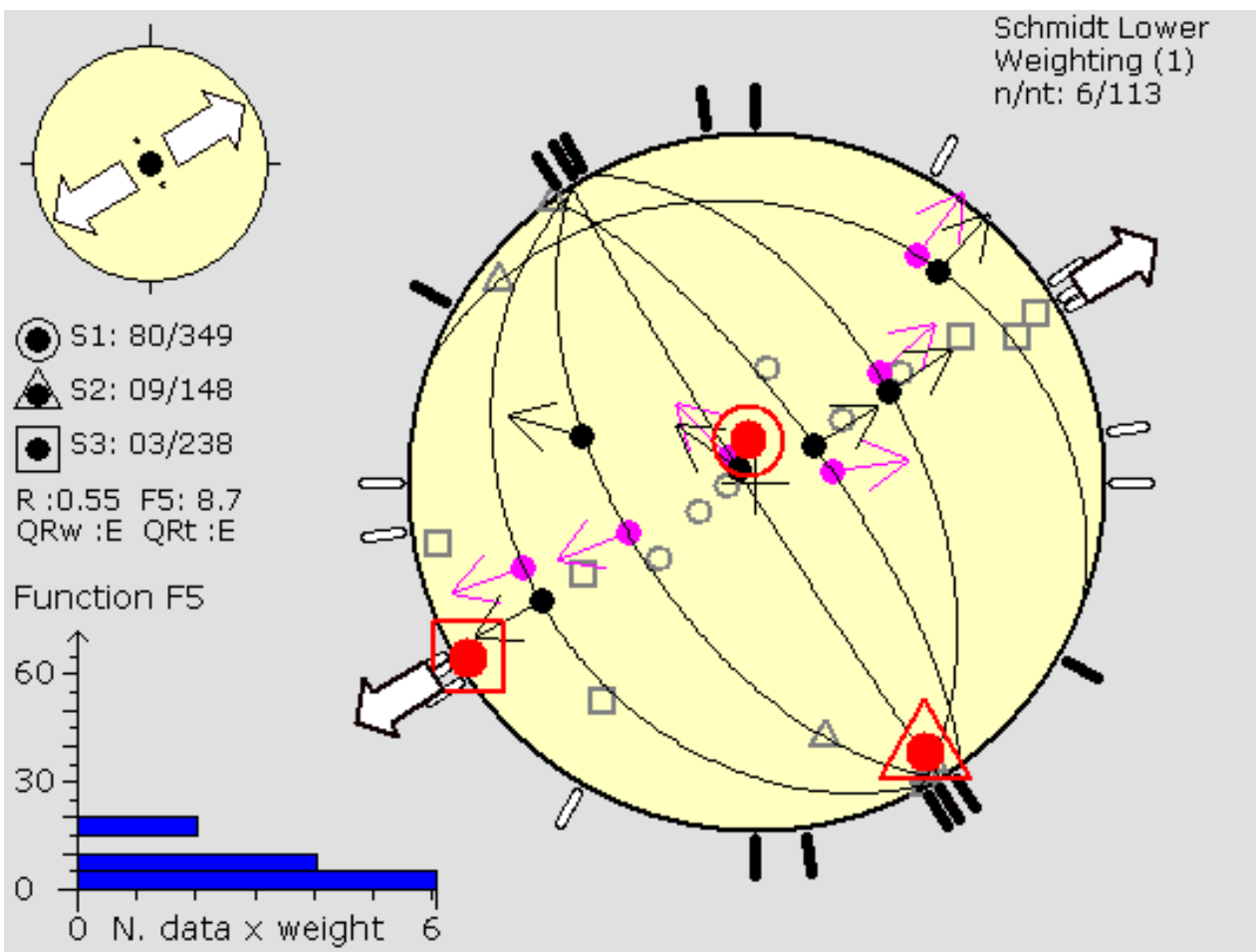

Fig. 14: NE-SW Pure Extension Stress State Deduced by Analysis of Normal Faults in Perat Anticline. 




Fig. 15: NW-SE Pure Extension Stress State Deduced by Analysis of Normal Faults in Perat Anticline.



Fig. 16:NNW-SSE Pure Extension Stress State Deduced by Analysis of Normal Faults in Perat Anticline. 




Fig. 17: P Axis Orientations Deduced by Analysis of Whole Faults Collectively in Perat Anticline Using GEORIENT Software.

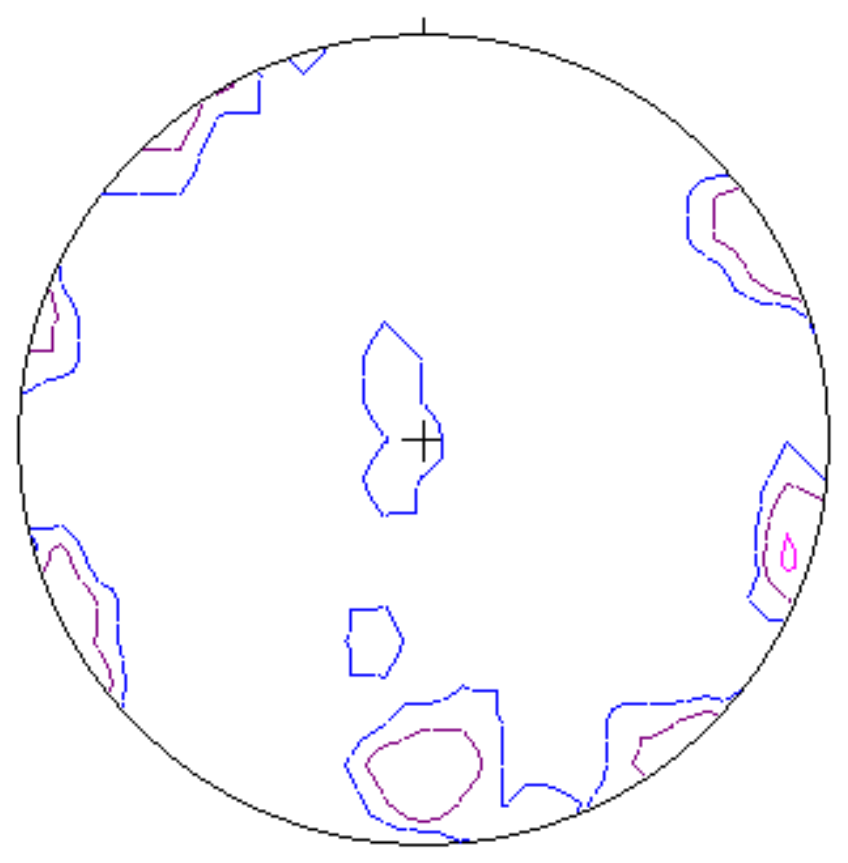

Fig. 18: T Axis Orientations Deduced by Analysis of Whole Faults Collectively in Perat Anticline Using GEORIENT Software. 


\section{DISCUSSION AND CONCLUSIONS}

Kinematic analysis and interpretation of brittle failure structures in the present investigation have revealed the following stress regimes:

1. A primary compressive regime with $\boldsymbol{\sigma}_{\text {Hmax. }}$ in NNE-SSW direction (approximately normal to Perat fold trend) and $\boldsymbol{\sigma}_{\mathrm{Hmin} .}$ in WNW-ESE direction (approximately parallel to Perat fold trend ). The dominant structures of this regime are widespread hko>a shear joints, ac tension joints and veins, bedding dip pointing stylolite peaks, and majority of reverse and strike slip faults expressed by stress tensors 1 and 4 respectively, besides to a little number of normal faults represented by tensor 8 ( Table 1 ).

2. A relaxation episode followed the primary compressive regime involved


fold trend (WNW-ESE) and $\boldsymbol{\sigma}_{\mathrm{Hmin}}$. normal to this trend. The brittle failure structures developed by this relaxation episode are widespread hko>b shear joints, bc tension joints and veins, bedding strike pointing stylolite peaks, and groups of reverse and normal faults expressed by tensors 3 and 7 respectively ( Table 1).

3. A subordinate compressive regime with $\boldsymbol{\sigma}_{\text {Hmax. }}$ in ENE-WSW and E-W directions. This regime might be related to the counterclockwise rotation of Arabian plate against Eurasian plate during their oblique collision. The developed structures by this regime are groups of reverse and strike slip faults represented by tensors 2 and 5 respectively. However, a little number of normal faults expressed by tensor 9 might be regarded as extensional byproduct $\left(\boldsymbol{\sigma}_{\mathrm{Hmin}}\right.$. in NNW-SSE direction) of this secondary regime (Table 1).

4. A relaxation episode of the above cited subordinate compressive regime is expressed by a group of strike slip faults and postulated by tensor 6 with $\boldsymbol{\sigma}_{\mathrm{Hmax}}$. in NNW-SSE direction (Table 1).

The above cited stress regimes were postulated also by other authors in the same region. Al-Fadhli et al., (1979, 1980) had concluded two subsequent compressive stress directions in NE-SW and NW-SE through analysis of fold style and accompanied fractures in Sayed Sadeq and Peramagron anticlines NE Iraq. Taha et al., (1995) recognized also three tectonic stress regimes via analyzing microtectonic elements at Dokan area NE Iraq. The first two are compressive in NNE-SSW and EW directions respectively. The third one is extensional and in NW-SW direction. Further, Taha (1995) has emphasized two tectonic stress regimes, a compressive one in NE-SW direction and an extensional in a transverse direction to the first at Safine anticline NE Iraq.

\section{REFERENCES}

Agard, P., Omrani, J., Jolivet, J., and Mouthereau, F., 2005. Convergence History Across Zagros (Iran): Constraints from Collisional and Earlier Deformation. Inter. J. Earth Sci., Vol. 94, pp. 401 - 419. 
Alavi, M., 2004. Regional Stratigraphy of the Zagros Fold-Thrust Bbelt of Iran and its Proforeland Evolution. Amer. J. Sci., Vol. 304, pp. 1 - 20.

Al-Fadhli, I., Janardan Rao, Y., Oweiss, G. and Khalil, M., 1979. Polyphase Deformation in a Part of Zagors, Sulaimaniyah District, NE Iraq. J. Indian Acad. Geosci., Vol. 22, pp. 1 - 31.

Al-Fadhli, I., Janardan Rao, Y., Oweiss, G. and Takla, M.A., 1980. Superimposed Folding in Sayed-Sadek Area, Near the Zagors Suture Zone, Iraq. Geoviews, VIII, No. 111, pp. 126 - 148.

AL-Hamdani, R. K. H., 1991. Stratigraphy and Structure of the Southeastern Part of Perat Anticline (Bekhme area). Unpub. M.Sc. thesis, Mosul Univ., Iraq, (in Arabic).

Angelier, J., 1989. From Orientation to Magnitudes in Paleostress Using Fault Slip Data. J. Struct., Geol., Vol. 11, pp. 37 - 50.

Angelier, J.,1994. Fault slip analysis and paleostress reconstruction. In:Continental Deformation. Ed. P Hancock, Pergamon Oxford, 53-100.by the Mawat and Penjwin Ophiolite Complexes. Raf. J. Sci., Vol. 10, No. 1, pp. 51 - 61.

Authemayou, C., Chardon, D., Bellier, O., Malekzadeh, Z., Shabanian,E., and Abbassi, M. R., 2006. Late Cenozoic Partitioning of Oblique Plate Convergence in the Zagros Fold-and-Thrust Belt(Iran).Tectonics,25, TC,3002. Belayneh, M., 2004. Paleostress Orientation Inferred from Surface Morphology of Joints on the Southern Margin of the Bristol Channel Basin, UK. In The Initiation, Propagation, and Arrest of Joints and other Fractures Edited by J.W. Cosgrove and T. Engelder. Geol. Soc., London, Special Publication, Vol. 231, pp. 243 - 255.

Bl'es, J.L. and Feuga, B., 1986. The Fracture of Rocks. North Oxford Academic Publishers Ltd., 131p.

Bucher, F., 1981. Rhine Graben: Horizontal Stylolites Indicating Stress Regimes of Earlier States of Rifting. Tectonophy., Vol. 73, pp. 113 - 118.

Davis, H. and Reynolds, J., 1996. Structural Geology of Rocks and Regions. John Wiley and Sons, INC. New York, $776 \mathrm{p}$.

Delvaux, D. and Sperner, B., 2003. Stress Tensor Inversion from Fault kinematic Indicators and Focal Mechanism Data. The TENSOR Program. In: New Insights into Structural Interpretation and Modeling (D. Nieuwland Ed.). Geol. Soc. London, Special Publications, Vol. 212, pp. $75-100$.

Dune, W. M. and Hancock, P. L., 1994. Paleostress Analysis of Small-Scale Brittle Structures. In: Continental Deformation Edited by P.L. Hancock. Pergamon Press Ltd, Oxford, pp. 101 - 120

Georg Mandl, 2005. Rock Joints. The Mechanical Genesis. Springer Verlog Berlin Heidelberg, Nethwerlands.

Hancock, P.L., 1985. Brittle Microtectonics, Principles and Practice, J. Struct. Geol., Vol. 7, pp. 437 - 457.

Jassim S.Z., and Goff J.C., 2006. Geology of Iraq. Published by Dolin, Prague and Musem, Brno Czech Republic, 2006. 337 p. 
Mitra, S., 2002. Fold-Accommodation Faults. AAPG Bulletin, Vol. 86, No. 4, pp. $671-693$.

Mohajjel, M., Fergusson, C. L., and Sahandi, M. R., 2003. Cretaceous-Tertiary Convergence and Continental Collision, Sanandaj-Sirjan Zone, Western Iran. J. Asian Earth Sci., Vol. 21, pp. 397 - 412.

Molinaro, M., Leturmy, P., Guezou, J. C., Frizon de Lamotte, D., and Eshraghi, S.A., 2005. The Structure and kinematics of the South-Eastern Zagros Fold Thrust Belt; Iran: from Thin-Skinned to Thick-Skinned Tectonics. Tectonics, Vol. 24, TC3007.

Nicolas, A., 1987. Principle of Rock Deformation; D. Reidel Published CO. Netherland, 208 p.

Numan, N. M. S., 1997. A Plate Tectonic Scenario for the Phanerozoic Succession in Iraq. J. Geol. Soc. Iraq, Vol. 30, No. 2.

Numan, N. M. S., 2001a. Cretaceous and Tertiary Alpine Subductional History in Northern Iraq. Iraqi Jour. Earth Sci., Vol. 1, No. 2.

Numan, N. M. S., 2001b. Discussion on "Dextral Transpression in Late Cretaceous Continental Collision, Sanandaj - Sinjar Zone, Western Iran". J. Struct. Geol., Vol. 23.

Omar, A. A., 2005. An Integral Structural and Tectonic Study of the Binabawi Safin - Bradost Region in Iraqi Kurdistan. Unpublished PH.D. Thesis, Salahadin Univ., Iraq.

Ramsay, J. G. and Huber, M. I., 1987. Folds and Fractures :The Techniques of Modern Structural Geology, Vol. 2, New York, Academic Press, 700 p.

Scheidegger, A. E., 2001. Surface Joint Systems, Tectonic Stresses and Geomorphology: A Reconciliation of Conflicting Observations. Geomorph., Vol. 38, pp. 213 - 219.

Shadmon, A., 2008. Stylolites, A diagnostic tool. Retrieved from www. litosonline. com/articles/73/ar730ue.shtml.

Smith, J.V., 1996. Geometry and Kinematics of Convergent Conjugate Vein Array Systems. J. Struct. Geol., Vol. 18, pp. 1291 - 1300.

Taha, M. A., Al-Saadi, S. N. and Ibrahim, I. S., 1995. Micro Tectonic Study of Dokan Area, NE Iraq. J. Geol. Soc. Iraq, Vol. 28, No. 1, pp. 25 - 35.

Taha, M. A., 1995. Determination of Tectonic Phases Direction from Fault Striation Measurements in Salahudin - Shaqlawa Area, Northern Iraq. J. Geol. Soc. Iraq, Vol. 28, No. 2, pp. $12-19$

Talebian, M. and Jackson, J., 2002. Offset on the Main Recent Fault of NW Iran and Implications for the Late Cenozoic Tectonics of the Arabia-Eurasia Collision Zone. Geophy. J. Inter., Vol. 150, pp. 422 - 439.

Van Der Pluijm, B. A. and Marshak, S., 1997. Earth Structure : An Introduction to Structural Geology and Tectonics WCB/McGraw Hill, USA, 495p. 